\title{
Plasmodium falciparum infection rates for some Anopheles spp. from Guinea-Bissau, West Africa [version 1; peer review: 2
}

\section{approved]}

\author{
Michelle R. Sanford1', Anthony J. Cornel1,3, Catelyn C. Nieman1, Joao Dinis², \\ Clare D. Marsden 1 , Allison M. Weakley1', Sarah Han1, Amabelia Rodrigues², \\ Gregory C. Lanzaro (D1, Yoosook Lee ${ }^{1}$
}

${ }^{1}$ Vector Genetics Laboratory, Department of Pathology, Microbiology, and Immunology, School of Veterinary Medicine, University of California, Davis, CA, 95616, USA

${ }^{2}$ National Institute of Public Health (INASA), Bissau, Guinea-Bissau

${ }^{3}$ Department of Entomology and Nematology, University of California, Davis, CA, 95616, USA

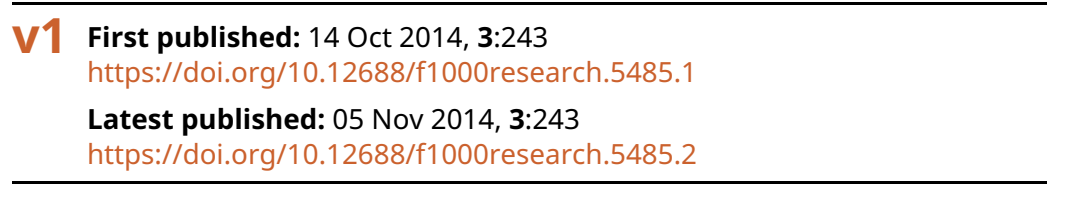

\section{Abstract}

Presence of Plasmodium falciparum circumsporozoite protein (CSP) was detected by enzyme linked immunosorbent assay (ELISA) in a sample of Anopheles gambiae s.s., A. melas and A. pharoensis collected in Guinea-Bissau during October and November 2009. The percentage of $P$. falciparum infected samples (10.2\% overall) was comparable to earlier studies from other sites in Guinea-Bissau (9.6-12.4\%). The majority of the specimens collected were identified as $A$. gambiae which had an individual infection rate of $12.6 \%$ across collection sites. A small number of specimens of $A$. coluzzii, $A$. coluzzii $\times$ A. gambiae hybrids, $A$. melas and $A$. pharoensis were collected and had infection rates of $4.3 \%, 4.1 \%, 11.1 \%$ and $33.3 \%$ respectively. Despite being present in low numbers in indoor collections, the exophilic feeding behaviors of $A$. melas $(\mathrm{N}=18)$ and $A$. pharoensis $(\mathrm{N}=6)$ and high infection rates observed in this survey suggest falciparum-malaria transmission potential outside of the protection of bed nets.

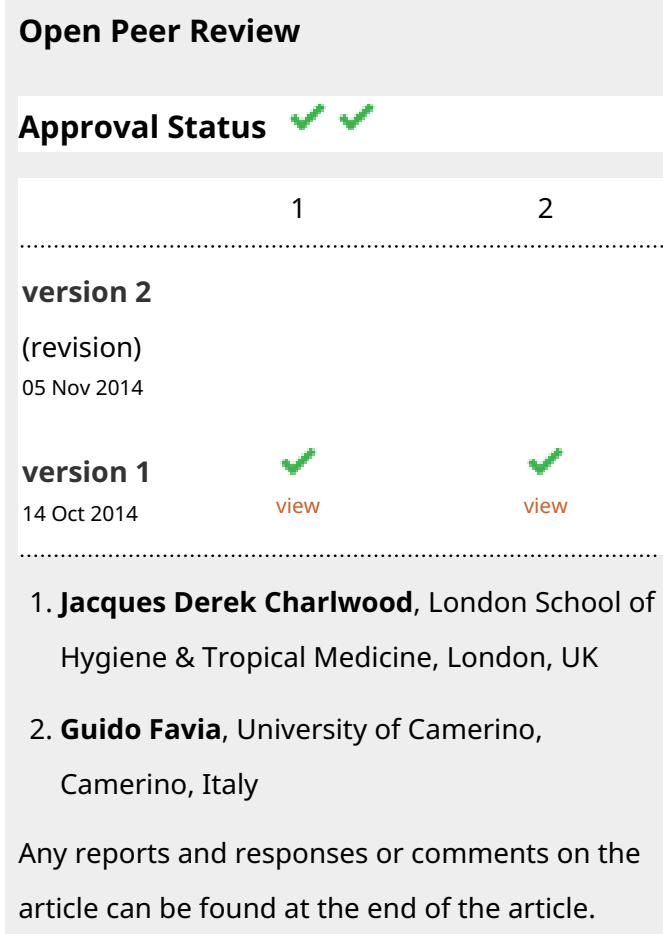

1 2

version 2

(revision)

05 Nov 2014

version 1

14 Oct 2014

1. Jacques Derek Charlwood, London School of Hygiene \& Tropical Medicine, London, UK

2. Guido Favia, University of Camerino,

Camerino, Italy

Any reports and responses or comments on the article can be found at the end of the article. 
Corresponding author: Yoosook Lee (yoslee@ucdavis.edu)

Competing interests: No competing interests were disclosed.

Grant information: The authors also acknowledge financial support from NIH grants: 5R21AI062929 and 5T32AI074550.

The funders had no role in study design, data collection and analysis, decision to publish, or preparation of the manuscript.

Copyright: @ 2014 Sanford MR et al. This is an open access article distributed under the terms of the Creative Commons Attribution License, which permits unrestricted use, distribution, and reproduction in any medium, provided the original work is properly cited. Data associated with the article are available under the terms of the Creative Commons Zero "No rights reserved" data waiver (CC0 1.0 Public domain dedication).

How to cite this article: Sanford MR, Cornel AJ, Nieman CC et al. Plasmodium falciparum infection rates for some Anopheles spp. from Guinea-Bissau, West Africa [version 1; peer review: 2 approved] F1000Research 2014, 3:243 https://doi.org/10.12688/f1000research.5485.1

First published: 14 Oct 2014, 3:243 https://doi.org/10.12688/f1000research.5485.1 


\section{Introduction}

Malaria is among the leading causes of childhood mortality in Guinea-Bissau, comprising $18 \%$ of mortality of children less than five years of age as of 2010 (WHO, 2010). However, the human malaria incidence rate in Guinea Bissau varies considerably from year to year with a general decrease in recent years to about 3 children ( $<5$ yrs of age) per thousand in some locations (Ursing et al., 2014). Plasmodium falciparum predominates, causing $98 \%$ cases, followed by a few cases of Plasmodium malaria and Plasmodium ovale. Mixed infections of $P$. malariae, and to a lesser extent $P$. ovale, have been recorded but appear to be rare and highly variable in both Guinea-Bissau (Snounou et al., 1993) and neighboring Senegal (Fontenille et al., 1997a; Fontenille et al. 1997b).

Limited research has been conducted on the vectors and malaria parasite infection rates in Guinea-Bissau populations of Anopheles species in general and there is no data on comparative infection rates between A. gambiae and A. coluzzii and members of A. gambiae complex. Variability is also high among the Anopheles spp. implicated as vectors in this region of West Africa in terms of both their temporal population dynamics as well as species composition among study sites (Carnevale et al., 2010; Fontenille et al., 1997a; Jaenson et al., 1994; Snounou et al., 1993).

Here we present much needed data on $P$. falciparum infection of Anopheles spp. specimens collected from inside and around associated human habitations at eight sites in Guinea-Bissau (Table 1).

\section{Method}

Mosquitoes were collected by mouth aspiration from both the island and inland areas of Guinea-Bissau (Figure 1) in 2009 between October and November, which corresponds with the time of year previously observed to have the highest infection rate in Anopheles species (Jaenson et al., 1994). The mosquito was dissected and the head and thorax were preserved in $100 \%$ ethanol for subsequent ELISA. Genomic DNA was extracted using a DNeasy extraction kit

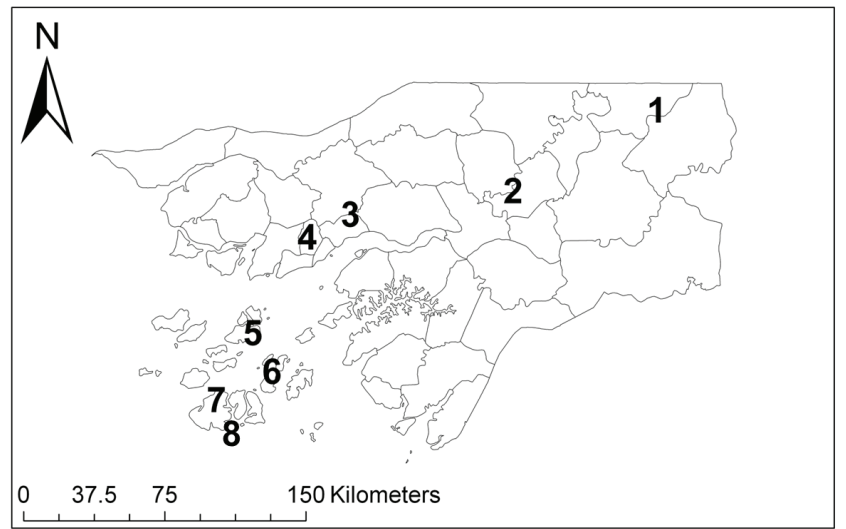

Figure 1. Collection sites in Guinea-Bissau. 1: Canjufa (12.43N, 14.13W), 2: Bambadinca (12.02N, 14.86W), 3: Antula (11.91N, 15.58W), 4: Prabis (11.80N, 15.74W), 5: Abu (11.46N, 15.91W), 6: Brus (11.23N, 15.88W), 7: Ponta Anabaca (11.18N, 16.14W) and 8: Eticoga (11.16N, $16.14 \mathrm{~W})$
Table 1. Sites, species and Plasmodium falciparum circumsporozoite protein (CSP) detection information from Anopheles spp. samples collected in Guinea-Bissau, October and November 2009. Numbers (\#) indicate site locations on the map of Guinea-Bissau in Figure 1. All mosquitoes were collected indoors with a single exception; samples in Ponta Anabaca were opportunistically collected outside.

\begin{tabular}{|c|c|c|c|c|c|}
\hline$\#$ & Site & $\begin{array}{l}\text { P. falciparum } \\
\text { infected }\end{array}$ & Uninfected & $\begin{array}{l}\text { Total } \\
\text { collected }\end{array}$ & $\begin{array}{l}\text { Infection } \\
\text { rate }\end{array}$ \\
\hline \multicolumn{6}{|c|}{ Anopheles coluzzii } \\
\hline 1 & Canjufa & 0 & 1 & 1 & $0.0 \%$ \\
\hline 2 & Bambadinca & 2 & 16 & 18 & $11.1 \%$ \\
\hline 3 & Antula & 0 & 17 & 17 & $0.0 \%$ \\
\hline 4 & Prabis & 0 & 24 & 24 & $0.0 \%$ \\
\hline 5 & Abu & 1 & 7 & 8 & $12.5 \%$ \\
\hline 6 & Brus & 0 & 1 & 1 & $0.0 \%$ \\
\hline 8 & Eticoga & 0 & 1 & 1 & $0.0 \%$ \\
\hline & SUBTOTAL & 3 & 67 & 70 & $4.3 \%$ \\
\hline \multicolumn{6}{|c|}{ Anopheles gambiae } \\
\hline 1 & Canjufa & 1 & 1 & 2 & $50.0 \%$ \\
\hline 2 & Bambadinca & 0 & 1 & 1 & $0.0 \%$ \\
\hline 3 & Antula & 13 & 63 & 76 & $17.1 \%$ \\
\hline 4 & Prabis & 3 & 50 & 53 & $5.7 \%$ \\
\hline 5 & Abu & 1 & 30 & 31 & $3.2 \%$ \\
\hline 6 & Brus & 0 & 5 & 5 & $0.0 \%$ \\
\hline 7 & $\begin{array}{l}\text { Ponta } \\
\text { Anabaca }\end{array}$ & 8 & 46 & 54 & $14.8 \%$ \\
\hline 8 & Eticoga & 3 & 5 & 8 & $37.5 \%$ \\
\hline & SUBTOTAL & 29 & 201 & 230 & $12.6 \%$ \\
\hline \multicolumn{6}{|c|}{ A. coluzzii x A. gambiae hybrids } \\
\hline 1 & Canjufa & 1 & 0 & 1 & $100.0 \%$ \\
\hline 3 & Antula & 1 & 26 & 27 & $3.7 \%$ \\
\hline 4 & Prabis & 0 & 14 & 14 & $0.0 \%$ \\
\hline 5 & Abu & 0 & 5 & 5 & $0.0 \%$ \\
\hline 8 & Eticoga & 0 & 2 & 2 & $0.0 \%$ \\
\hline & SUBTOTAL & 2 & 47 & 49 & $4.1 \%$ \\
\hline \multicolumn{6}{|c|}{ Anopheles melas } \\
\hline 3 & Antula & 1 & 2 & 3 & $33.3 \%$ \\
\hline 4 & Prabis & 1 & 7 & 8 & $12.5 \%$ \\
\hline 5 & Abu & 0 & 2 & 2 & $0.0 \%$ \\
\hline 6 & Brus & 0 & 6 & 6 & $0.0 \%$ \\
\hline 8 & Eticoga & 0 & 1 & 1 & $0.0 \%$ \\
\hline & SUBTOTAL & 2 & 16 & 18 & $11.1 \%$ \\
\hline \multicolumn{6}{|c|}{ Anopheles pharoensis } \\
\hline 2 & Bambadinca & 2 & 4 & 6 & $33.3 \%$ \\
\hline & Grand Total & 38 & 337 & 375 & $10.2 \%$ \\
\hline
\end{tabular}


(Qiagen). Species determination of mosquitoes from the A. gambiae complex were made with the combination of species diagnostic assays (Fanello et al., 2002; Favia et al., 2001; Santolamazza et al., 2008; Scott et al., 1993) and a divergence island SNP (DIS) genotyping assay (Lee et al., 2014) while other species were identified by morphology.

For the Scott PCR (Scott et al., 1993) and the Fanello RFLP (Fanello et al., 2002), we used four primers (UN [5'-GTG TGG CCC TTC CTC GAT GT-3'], GA [5'-CTG GTT TGG TCG GCA CGT TT-3'], ME [5'-TGA CCA ACC CAC TCC CTT GA-3'] and AR [5'-AAG TGT CCT TCT CCA TCC TA-3']). We excluded QD primer (Scott et al., 1993) because our study site is well outside of the geographic range of this species (East Africa). A $25 \mu \mathrm{L}$ PCR reaction containing $1 \mathrm{X}$ GeneAmp PCR Buffer (Applied Biosystems), 1mM $\mathrm{MgCl}_{2}, 0.2 \mathrm{mM}$ of each dNTP, $0.12 \mu \mathrm{M}$ of each primer and $0.05 \mathrm{U}$ AmpliTaq DNA polymerase (Applied Biosystems) was carried out for each individual. Scott PCR products were digested using Hha1 enzyme (New England Biosystems) following the protocol stated in (Fanello et al., 2002). Thermocycler conditions were $95^{\circ} \mathrm{C}$ for $5 \mathrm{~min}$ followed by thirty-five cycles of $95^{\circ} \mathrm{C}$ for $45 \mathrm{~s}, 50^{\circ} \mathrm{C}$ for $30 \mathrm{~s}$ and $72^{\circ} \mathrm{C}$ for $45 \mathrm{~s}$, with a final elongation at $72^{\circ} \mathrm{C}$ for $7 \mathrm{~min}$, and a $4^{\circ} \mathrm{C}$ hold.

For the Favia PCR (Favia et al., 2001), we used four primers (R5 [5'-GCC AAT CCG AGC TGA TAG CGC-3'], R3 [5'-CGA ATT CTA GGG AGC TCC AG-3'], Mopint [5'-GCC CCT TCC TCG ATG GCA T-3'] and B/S int [5'-ACC AAG ATG GTT CGT TGC-3']. A $25 \mu \mathrm{L}$ PCR reaction containing $1 \mathrm{X}$ PCR Buffer (Applied Biosystems), $1.5 \mathrm{mM} \mathrm{MgCl}, 0.2 \mathrm{mM}$ of each dNTP, $0.2 \mu \mathrm{M}$ of primer R5, $0.2 \mu \mathrm{M}$ of primer R3, $0.16 \mu \mathrm{M}$ of primer Mopint, $0.1 \mu \mathrm{M}$ of primer B/S int and 0.02U DNA polymerase AmpliTaq (Applied Biosystems) was carried out for each individual. Thermocycler conditions were $95^{\circ} \mathrm{C}$ for $5 \mathrm{~min}$ followed by thirty-five cycles of $95^{\circ} \mathrm{C}$ for $30 \mathrm{~s}, 64^{\circ} \mathrm{C}$ for $30 \mathrm{~s}$ and $72^{\circ} \mathrm{C}$ for $30 \mathrm{~s}$, with a final elongation at $72^{\circ} \mathrm{C}$ for $7 \mathrm{~min}$, and a $4^{\circ} \mathrm{C}$ hold.

For the SINEX PCR (Santolamazza et al., 2008), we used S200 X6.1 forward [5'-TCG CCT TAG ACC TTG CGT TA-3'] and reverse [5'-CGC TTC AAG AAT TCG AGA TAC-3'] primers. A $25 \mu \mathrm{L}$ PCR reaction containing $1 \mathrm{X}$ PCR Buffer (Applied Biosystems), $2 \mathrm{mM} \mathrm{MgCl}, 0.4 \mathrm{mM}$ of each dNTP, $0.2 \mu \mathrm{M}$ of each primer and 0.1U DNA polymerase AmpliTaq (Applied Biosystems) was carried out for each individual. Thermocycler conditions were $95^{\circ} \mathrm{C}$ for $5 \mathrm{~min}$ followed by thirty-five cycles of $95^{\circ} \mathrm{C}$ for $30 \mathrm{~s}, 60^{\circ} \mathrm{C}$ for $30 \mathrm{~s}$ and $72^{\circ} \mathrm{C}$ for $30 \mathrm{~s}$, with a final elongation at $72^{\circ} \mathrm{C}$ for $10 \mathrm{~min}$, and a $4^{\circ} \mathrm{C}$ hold.

The resulting PCR products were analyzed on a Qiaxcel capillary electrophoresis instrument (Qiagen) using a DNA Screening Cartridge (Qiagen).

For DIS genotyping, we used Sequenom iPLEX Gold Genotyping Reagent Set (Catalog number: Sequenom 10158) and ran on MassArray (Sequenom) mass spectrometer at UC Davis Veterinary Genetics Laboratory. A mosquito was considered a hybrid if at least 5 out of 7 DIS on the $\mathrm{X}$ chromosome were in a heterozygous state.
P. falciparum infection was determined by enzyme linked immunosorbent assay (ELISA) of circumsporozoite protein (CSP) (Burkot et al., 1984; Wirtz et al., 1987) from the head and thorax of mosquito specimens in an attempt to capture the parts of the mosquito that would indicate they were infective mosquitoes. All chemicals except for substrate solutions (Item 5 on page 5 of the supplemental ELSA protocol document) were ordered from Sigma-Aldrich. Monoclonal antibodies (capture and conjugate) were obtained from Kirkegaard \& Perry Laboratories. P. falciparum sporozoite protein for positive control was ordered from the Centers for Disease Control and Prevention (CDC). We followed the Sporozoite ELISA directions provided by the CDC (Sep, 2009 version) with a few modifications (see supplemental document for the modified ELISA protocol). Samples were considered positive if absorbance values were three or more standard deviations from the negative control samples (99\% CI) on each ELISA plate (Beier et al., 1987; De Arruda et al., 2004).

The results of the ELISA were analyzed for both CSP concentration, adjusted for plate-to-plate variation, with an analysis of variance and for a binary outcome using a $\chi^{2}$ test implemented in SPSS 16.0 (SPSS, 2007). The data were analyzed for differences between species and among collection sites, using G-test implemented in Deducer library under R software (http://www.r-project.org/). Species and $P$. falciparum infection state and CSP concentration for each individual is provided in Dataset 1.

\section{Results \& discussion}

ELISA results identifying Plasmodium falciparum infection status in Anopheles spp. collected in Guinea-Bissau

http://dx.doi.org/10.6084/m9.figshare.1200058

Mosquitoes were collected at eight different sites in Guinea-Bissau between October and November 2009. All mosquitoes were collected indoors except those collected at Ponta Anabaca which were collected outdoors. See associated article for methods.

Four species were collected during sampling; A. coluzzii, A. gambiae, A. melas, A. pharoensis and A. coluzzi x A. gambiae hybrids were observed. All mosquitoes were collected indoors with a single exception; samples in Ponta Anabaca were opportunistically collected outside of a human habitation while apparently host-seeking immediately after sunset at about 18:00 hr, which is earlier than reported observations for members of the A. gambiae complex in The Gambia (West Africa) (Lindsay et al., 1989; Snow et al., 1988). All species were collected at multiple sites except $A$. pharoensis, which was only collected at the more inland site of Bambadinca. A. pharoensis is not generally considered a significant vector in West Africa but the distribution observed in this study matches the previously observed pattern in Senegal (Carrara et al., 1990). Anopheles arabiensis was absent from collections.

No significant differences were observed for CSP concentration or in the analysis of positive samples with $\chi^{2}$. This is probably due to the variation in the distribution of vector species and $P$. falciparum in the environment at the time of sampling. Table 1 presents CSP rate data and the total number of each individual species collected at each site. 
The percentage of $P$. falciparum positive samples from members of the A. gambiae species complex observed in this study (overall $10.2 \%$ ) were similar to earlier studies in other regions in GuineaBissau (12.0\% (Snounou et al., 1993) and 9.6-12.4\% (Jaenson et al., 1994)). The overall CSP positive rate for A. gambiae was $12.6 \%$ and $11.1 \%$ for A. melas. Previously published CSP positive rates for $A$. gambiae s.s. (=A. gambiae and $A$. coluzzii) range between $2.24 \%$ in Guinea (Carnevale et al., 2010) to $9.6 \%$ in Guinea-Bissau (Jaenson et al., 1994). Earlier studies when individual species within the A. gambiae complex were not identified, infection rate of A. gambiae s.l. ranged from as high of $17.73 \%$ in the eastern regions of The Gambia (Thomson et al., 1994) to $12 \%$ in Guinea-Bissau (Jaenson et al., 1994; Snounou et al., 1993). The CSP positive rate was significantly higher in A. gambiae (12.6\%) than A. coluzzii $(4.3 \%)$ (Wilcoxon rank sum test $\mathrm{P}$-value $=0.0384)$. This is consistent with the earlier study in Senegal (Ndiath et al., 2011) but differs from a recent survey conducted in Mali (Fryxell et al., 2012). The study site in Senegal located in the village of Dielmo $\left(13^{\circ} 43^{\prime} \mathrm{N}\right.$, $\left.16^{\circ} 24^{\prime} \mathrm{W}\right)$ (Ndiath et al., 2012)) was geographically closer $(200 \mathrm{~km})$ than Mali sites $(>800 \mathrm{~km})$ to our collection sites in Guinea-Bissau. The Senegal study site at Dielmo and nine of our study sites were proximal $(<50 \mathrm{~km})$ to the Atlantic Ocean, while Mali is a landlocked country at least $500 \mathrm{~km}$ away from the Atlantic Ocean. Therefore, the discrepancy among studies may be due to climatic and environmental pressure on the different genetic backgrounds of A. gambiae observed in this area of West Africa (Lee et al., 2013). More robust sampling over a larger number of collection sites would help in confirming this trend.

In this study, a few A. pharoensis $(\mathrm{N}=6)$ were collected, half of which were CSP positive. Other studies in this region of West Africa have found that A. funestus and A. arabiensis may also be important vector species at different times in nearby Senegal (Fontenille et al., 1997a; Fontenille et al., 1997b). A. arabiensis was not collected in our study while a small number $(\mathrm{N}<10)$ of $A$. funestus were observed but not collected.

Recent studies on the prevalence of malaria parasites in humans have suggested that infection rates in Guinea-Bissau may be in decline due to widespread use of effective treatment and insecticide treated bed nets (ITNs and long lasting insecticide treated bed nets, LLINs) by the most high-risk groups (Rodrigues et al., 2008; Ursing et al., 2014). The malaria parasite life cycle is complicated and may not directly relate to the prevalence of human cases but it is possible that the lack of data during periods of political unrest has concealed a more stochastic pattern than was previously observed in Guinea-Bissau (Ursing et al., 2014).

Outdoor mosquito collection was not the focus of this survey and was only made at Ponta Anabaca Hotel grounds when we fortuitously noted mosquitoes biting. Consequently no general comments about the degree of exophily of A. gambiae in Guinea-Bissau can be made. However, evidence of exophily by the major malaria vector A. gambiae in this study and by others in West Africa (Reddy et al., 2011; Tchouassi et al., 2012) raises the concern of the long term effectiveness of Indoor Residual Spraying (IRS) and Long lasting Insecticide-treated Nets (LLINs) in reducing outdoor transmission of malaria especially before bedtime and by people sleeping outdoors. The relatively high infection rate of $11.1 \%$ of A. melas in Guinea-Bissau together with its tendencies to be both endophilic and exophilic and have a high human blood index (Sharp et al., 2007; Tuno et al., 2010) make the species a significant vector, which may also be hard to control by reliance on ITNs and LLINs.

The high CSP rate of $33.3 \%$ in the 4 indoor collected A. pharoensis might implicate a significant role in malaria transmission in drier inland Guinea Bissau, however this should be viewed with caution due the small sample size. Very low infection rates and absence of malarial parasites, traditionally found in West and Central African populations of $A$. pharoensis has always led to the conclusion that this mosquito plays little role in malaria transmission despite its anthropophilic habits and that it can be easily experimentally infected (DeMeillon, 1947; Ndiath et al., 2012; Tchouassi et al., 2012). In drier Sahel regions of Africa where the major vectors of malaria are absent or very rare and irrigated rice and other crop lands are increasing, A. pharoensis is considered more important at maintaining low levels of malaria (Kerah-Hinzoumbe et al., 2009; Kibret et al., 2010).

\section{Data availability}

figshare: ELISA results identifying Plasmodium falciparum infection status in Anopheles spp. collected in Guinea-Bissau. doi: 10.6084/m9.figshare.1200058 (Sanford et al., 2014).

\section{Author contributions}

YL, GCL and AJC conceived the study, designed experiments and conducted field collections. JD conducted field collection. AR provided logistical support and coordination for field collection in Guinea-Bissau. CCN, CDM, AMW and SH conducted DNA extraction, ELISA and PCR. MRS performed data analysis and wrote manuscript. All authors were involved in the revision of the draft manuscript and have agreed to the final content.

\section{Competing interests}

No competing interests were disclosed.

\section{Grant information}

The authors also acknowledge financial support from NIH grants: 5R21AI062929 and 5T32AI074550.

The funders had no role in study design, data collection and analysis, decision to publish, or preparation of the manuscript.

\section{Acknowledgements}

We thank Parker Goodell and Mike Kim for their assistance in DNA extraction, molecular form determination and ELISA processing. We thank Julia Malvick at the Veterinary Genetics Laboratory of UC Davis School of Veterinary Medicine for assistance in processing iPLEX SNP genotyping assay.

\section{Supplementary materials \\ Sporozoite ELISA Directions. Click here to access the supplement.}


Beier JC, Perkins PV, Wirtz RA, et al.: Field evaluation of an enzyme-linked immunosorbent assay (ELISA) for Plasmodium falciparum sporozoite detection in anopheline mosquitoes from Kenya. Am J Trop Med Hyg. 1987; 36(3): 459-468.

PubMed Abstract

Burkot TR, Williams JL, Schneider I: Identification of Plasmodium falciparuminfected mosquitoes by a double antibody enzyme-linked immunosorbent assay. Am J Trop Med Hyg. 1984; 33(5): 783-788.

PubMed Abstract

Carnevale P, Toto JC, Guibert P, et al:: Entomological survey and report of a knockdown resistance mutation in the malaria vector Anopheles gambiae from the Republic of Guinea. Trans R Soc Trop Med Hyg. 2010; 104(7): 484-489. PubMed Abstract | Publisher Full Text

Carrara GC, Petrarca V, Niang M, et al:: Anopheles pharoensis and transmission of Plasmodium falciparum in the Senegal River delta, West Africa. Med Vet Entomol. 1990; 4(4): 421-424.

PubMed Abstract | Publisher Full Tex

De Arruda ME, Collins KM, Collins LP, et al.: Quantitative determination of sporozoites and circumsporozoite antigen in mosquitoes infected with Plasmodium falciparum or P. vivax. Ann Trop Med Parasitol. 2004; 98(2): 121-127. PubMed Abstract | Publisher Full Text

De Meillon B: The Anophelini of the Ethiopian geographical region. The South African Institute for Medical Research. 1947.

Reference Source

Fanello C, Santolamazza F, della Torre A: Simultaneous identification of species and molecular forms of the Anopheles gambiae complex by PCR-RFLP. Med Vet Entomol. 2002; 16(4): 461-464.

PubMed Abstract | Publisher Full Text

Favia G, Lanfrancotti A, Spanos L, et al.: Molecular characterization of ribosomal DNA polymorphisms discriminating among chromosomal forms of Anopheles gambiae s.s. Insect Mol Biol. 2001; 10(1): 19-23.

PubMed Abstract | Publisher Full Text

Fontenille D, Lochouarn L, Diagne N, et al: High annual and seasonal variations in malaria transmission by anophelines and vector species composition in Dielmo, a holoendemic area in Senegal. Am J Trop Med Hyg. 1997a; 56(3): 247-253.

PubMed Abstract

Fontenille D, Lochouarn L, Diatta M, et al:: Four years' entomological study of the transmission of seasonal malaria in Senegal and the bionomics of Anopheles gambiae and A. arabiensis. Trans R Soc Trop Med Hyg. 1997b; 91(6): 647-652.

PubMed Abstract | Publisher Full Tex

Fryxell RT, Nieman CC, Fofana A, et al.: Differential Plasmodium falciparum infection of Anopheles gambiae s.s. molecular and chromosomal forms in Mali. Malar J. 2012; 11: 133

PubMed Abstract | Publisher Full Text | Free Full Text

Jaenson TG, Gomes MJ, Barreto dos Santos RC, et al.: Control of endophagic Anopheles mosquitoes and human malaria in Guinea Bissau, West Africa by permethrin-treated bed nets. Trans R Soc Trop Med Hyg. 1994; 88(6): 620-624. PubMed Abstract | Publisher Full Text

Kerah-Hinzoumbé C, Péka M, Antonio-Nkondjio C, et al: Malaria vectors and transmission dynamics in Goulmoun, a rural city in south-western Chad. BMC Infect Dis. 2009; 9: 71

PubMed Abstract | Publisher Full Text | Free Full Text

Kibret S, Alemu Y, Boelee $\mathrm{E}$, et al: The impact of a small-scale irrigation scheme on malaria transmission in Ziway area, Central Ethiopia. Trop Med Int Health. 2010; 15(1): 41-50.

PubMed Abstract | Publisher Full Text

Lee Y, Marsden CD, Nieman C, et al:: A new multiplex SNP genotyping assay for detecting hybridization and introgression between the $\mathrm{M}$ and $\mathrm{S}$ molecular forms of Anopheles gambiae. Mol Ecol Resour. 2014; 14(2): 297-305.

PubMed Abstract | Publisher Full Text | Free Full Text

Lee $Y$, Marsden CD, Norris LC, et al:: Spatiotemporal dynamics of gene flow and hybrid fitness between the $\mathrm{M}$ and $\mathrm{S}$ forms of the malaria mosquito, Anopheles gambiae. Proc Natl Acad Sci U S A. 2013; 110(49): 19854-19859.

PubMed Abstract | Publisher Full Text | Free Full Text

Lindsay SW, Shenton FC, Snow RW, et al.: Responses of Anopheles gambiae complex mosquitoes to the use of untreated bednets in The Gambia. Med Vet Entomol. 1989; 3(3): 253-262.

PubMed Abstract | Publisher Full Text

Ndiath MO, Cohuet A, Gaye A, et al:: Comparative susceptibility to Plasmodium falciparum of the molecular forms $\mathrm{M}$ and $\mathrm{S}$ of Anopheles gambiae and Anopheles arabiensis. Malar J. 2011; 10: 269.

PubMed Abstract | Publisher Full Text | Free Full Text

Ndiath MO, Sarr JB, Gaaye L, et al:: Low and seasonal malaria transmission in the middle Senegal River basin: identification and characteristics of Anopheles vectors. Parasit Vectors. 2012; 5: 21

PubMed Abstract | Publisher Full Text | Free Full Text

Reddy MR, Overgaard HJ, Abaga S, et al.: Outdoor host seeking behaviour of Anopheles gambiae mosquitoes following initiation of malaria vector contro on Bioko Island, Equatorial Guinea. Malar J. 2001; 10: 184

PubMed Abstract | Publisher Full Text | Free Full Text

Rodrigues $\mathrm{A}$, Schellenberg JA, Kofoed $\mathrm{PE}$, et al:: Changing pattern of malaria in Bissau, Guinea Bissau. Trop Med Int Health. 2008; 13(3): 410-417.

PubMed Abstract | Publisher Full Text

Sanford M, Cornel AJ, et al.: ELISA results identifying Plasmodium falciparum infection status in Anopheles spp. collected in Guinea-Bissau. figshare. 2014. Data Source

Santolamazza F, Mancini E, Simard F, et al.: Insertion polymorphisms of SINE200 retrotransposons within speciation islands of Anopheles gambiae molecular forms. Malar J. 2008; 7: 163

PubMed Abstract | Publisher Full Text | Free Full Text

Scott JA, Brogdon WG, Collins FH: Identification of single specimens of the Anopheles gambiae complex by the polymerase chain reaction. Am J Trop Med Hyg. 1993; 49(4): 520-529.

PubMed Abstract

Sharp BL, Ridl FC, Govender D, et al.: Malaria vector control by indoor residual insecticide spraying on the tropical island of Bioko, Equatorial Guinea. Malar J. 2007; 6: 52.

PubMed Abstract | Publisher Full Text | Free Full Text

Snounou G, Pinheiro L, Goncalves A, et al:: The importance of sensitive detection of malaria parasites in the human and insect hosts in epidemiological studies, as shown by the analysis of field samples from Guinea Bissau. Trans R Soc Trop Med Hyg. 1993; 87(6): 649-653.

PubMed Abstract | Publisher Full Text

Snow RW, Rowan KM, Lindsay SW, et al:: A trial of bed nets (mosquito nets) as a malaria control strategy in a rural area of The Gambia, West Africa. Trans $R$ Soc Trop Med Hyg. 1988; 82(2): 212-215.

PubMed Abstract | Publisher Full Text

SPSS I: SPSS Graduate Pack 16.0 for Windows, pp., Chicago, IL. 2007.

Tchouassi DP, Quakyi IA, Addison EA, et al: Characterization of malaria transmission by vector populations for improved interventions during the dry season in the Kpone-on-Sea area of coastal Ghana. Parasit Vectors. 2012; 5: 212. PubMed Abstract | Publisher Full Text | Free Full Text

Thomson MC, D'Alessandro U, Bennett S, et al:: Malaria prevalence is inversely related to vector density in The Gambia, West Africa. Trans $R$ Soc Trop Med Hyg. 1994; 88(6): 638-643.

PubMed Abstract | Publisher Full Text

Tuno N, Kjaerandsen J, Badu K, et al:: Blood-feeding behavior of Anopheles gambiae and Anopheles melas in Ghana, western Africa. $J$ Med Entomol. 2010; 47(1): 28-31.

PubMed Abstract | Publisher Full Text

Ursing J, Rombo L, Rodrigues A, et al.: Malaria transmission in Bissau, GuineaBissau between 1995 and 2012: malaria resurgence did not negatively affect mortality. PLoS One. 2014: 9(7): e101167.

PubMed Abstract | Publisher Full Text | Free Full Text

WHO: Guinea-Bissau Factsheets of Health Statistics 2010, pp. World Health

Organization. 2010.

Reference Source

Wirtz RA, Zavala F, Charoenvit $Y$, et al.: Comparative testing of monoclonal antibodies against Plasmodium falciparum sporozoites for ELISA development. Bull World Health Organ. 1987; 65(1): 39-45.

PubMed Abstract | Free Full Text 


\section{Open Peer Review}

\section{Current Peer Review Status:}

\section{Version 1}

Reviewer Report 23 October 2014

https://doi.org/10.5256/f1000research.5855.r6412

(C) 2014 Favia G. This is an open access peer review report distributed under the terms of the Creative Commons Attribution License, which permits unrestricted use, distribution, and reproduction in any medium, provided the original work is properly cited.

\section{Guido Favia}

School of Bioscience and Veterinary Medicine, University of Camerino, Camerino, Italy

This "observation article" is very well written in a format that is accessible to both general and specialist audience. It describes some novel observations about malaria infection rates in different vector species in Guinea-Bissau. In particular it reports the some how unexpected high infection rates in Anopheles melas and $A$. pharoensis, thus suggesting Plasmodium falciparum-malaria transmission potential outside of protection (i.e. bed nets).

Details about the circumstances of the finding and evidence of the observation are properly provided. The manuscript appropriately cites relevant bibliography in the field. Figures and tables are informative and helpful. Methods section is well organized and nicely descriptive.

As observational article it looks perfectly adequate to the journal purpose.

I have only a very minor concern: in the Introduction (line 8) Plasmodium malaria should be rewritten as Plasmodium malariae.

Competing Interests: No competing interests were disclosed.

I confirm that I have read this submission and believe that I have an appropriate level of expertise to confirm that it is of an acceptable scientific standard.

Reader Comment 31 Oct 2014

Yoosook Lee, UC Davis, USA

Thank you very much for your review. Revisions to the manuscript were made as suggested.

Competing Interests: No competing interests were disclosed. 
Reviewer Report 22 October 2014

https://doi.org/10.5256/f1000research.5855.r6413

(C) 2014 Charlwood J. This is an open access peer review report distributed under the terms of the Creative Commons Attribution License, which permits unrestricted use, distribution, and reproduction in any medium, provided the original work is properly cited.

\section{Jacques Derek Charlwood}

London School of Hygiene \& Tropical Medicine, London, UK

This paper provides information on sporozoite rates from a relatively unstudied area the mainland and islands of Guinea Bissau. It gives the impression that it is a spin off from another study that perhaps aimed at characterizing the genetics of populations of Anopheles gambiae from the mainland and the islands, perhaps for future genetic control efforts. Given the widespread use of mosquito bednets rates are exceptionally high and not, apparently different from rates recorded earlier. The authors do make the comment that this might be the result of civil strife in GuineaBissau but whatever the cause this is disquieting and implies that the gains in reduction of malaria are going to be at best temporary.

The data are presented without confidence intervals but these should be added. Given the relatively small numbers involved either adjusted Wald confidence intervals (that can easily be calculated using the site www.measuringu.com/wald.htm or a routine in R) can, I think, be used. (But since I am signing this review everyone should know that my statistical abilities are limited!

The kind of collection undertaken needs to be explained in more detail. Were the mosquitoes collected resting or were they landing collections? I do not really want to be the person raising this issue but something on ethics should be included somewhere. (My own thoughts on ethics in general is that if the rule of 'first do no harm and second maybe do some good' is followed then a study - that may include even ad hoc landing collections - is not unethical.) This is especially important if the collections were landing collections.

To avoid possible misunderstanding, the sentence 'Four species were collected during sampling; $A$. coluzzii, A. gambiae, A. melas, A. pharoensis and A. coluzzi x A. gambiae hybrids were observed ' should be rewritten (since it could be misinterpreted) perhaps as two sentences: 'Four species, $A$. coluzzii, A. gambiae, A. melas, A. pharoensis were collected during sampling. A number of $A$. coluzzi $x$ A. gambiae hybrids were also collected'

There are a number of small errors in the paper that need to be rectified. For example in the last paragraph they state ' $33 \%$ of the 4 Anopheles pharoensis collected indoors when they either mean $33 \%$ of the six Anopheles pharoensis collected or $50 \%$ of the four collected indoors. With regard to this species it may be worth pointing out that in Mozambique none of the 4390 tested were positive for sporozoites (Charlwood et al., 2013) but at the same time in Ghana, (Dzodzomenyo et al., 1999) found that two of three specimens of An. pharoensis examined were infected (with Bancrotian filariasis) and one of these was infectious. Given the possibility of false positives among primarily zoophilic anophelines (that may also include An. melas) and given that the authors have access to a sophisticated laboratory it is a shame that they did not run a PCR on the 
sporozoite positive specimens to ensure that they were indeed human malarias.

Competing Interests: No competing interests were disclosed.

I confirm that I have read this submission and believe that I have an appropriate level of expertise to confirm that it is of an acceptable scientific standard.

Reader Comment 31 Oct 2014

Yoosook Lee, UC Davis, USA

Thank you very much for your review. Revisions to the manuscript will be made as suggested.

WIth respect to you comment about $\mathrm{CI}$, the data presented in the table are not replicated but a simple calculation of the percent of the total collection that were infected. We did not replicate within time or locations. Therefore there is no variation to report in the table.

About the concern related to outdoor mosquito collection, our only outdoor collection is from Ponta Anabaca where the hotel was located where we stayed. While we were processing our sample collections in the early evening at the hotel, we (Drs. Cornel, Lee and Lanzaro) were harassed by mosquitoes, which we identified as Anophelines by morphology. Although this was unplanned ad hoc landing collections, we were all taking anti-malaria prophylaxis at the time.

About the concern you raised about false positive of ELISA, this is a possibility for any test of parasite detection. We specifically chose to use the $P$. falciparum circumsporozoite protein sensitive ELISA test on the parts of the mosquito most likely to contain the infective stages (head and thorax) to minimize false positives in the results. Unfortunately the ELISA test was destructive and these specific parts of the mosquito have long been discarded. The DNA from the remainder of each mosquito has been archived but this contains the abdomen which presents another potential source of false positives as the gut contents may contain material that may never progress to rendering the mosquito infective.

Another confounding factor associated with using this type of testing is that it needs to be conducted more rapidly than the DNA extraction from the rest of the mosquito and the ELISA tests were often performed before the mosquito identification via PCR could be conducted. Such that an unusual result such as the one observed here would not have been detected until the ELISA samples had been discarded. It would definitely be beneficial to keep this in mind for future work in this area.

Competing Interests: No competing interests were disclosed.

\section{Comments on this article}




\section{Version 1}

Author Response 16 Oct 2014

Yoosook Lee, UC Davis, USA

The infection rate is conservative (using $99 \%$ CI for calling uninfected samples). The infection rate estimates are higher with 95\% CI.

Competing Interests: I am an author of this paper.

The benefits of publishing with F1000Research:

- Your article is published within days, with no editorial bias

- You can publish traditional articles, null/negative results, case reports, data notes and more

- The peer review process is transparent and collaborative

- Your article is indexed in PubMed after passing peer review

- Dedicated customer support at every stage

For pre-submission enquiries, contact research@f1000.com 